\title{
AN OVERVIEW ON DAIRY INDUSTRY WASTEWATER AND ITS INDIAN SCENARIO
}

\author{
Vibha Agrawal \\ Department of General Engineering \\ Institute of Chemical Technology, Mumbai, \\ Maharashtra, India- 400019
}

\begin{abstract}
The dairy industry continues to grow with the growing population. It is considered the most polluting industry in terms of water consumption and wastewater generation. It generates about 6 to 10 litres of organically loaded effluent per litre of milk processed depending upon the products manufactured. Indian Standard (IS) 8682:1977 gives the guidelines for the treatment and disposal of dairy wastewater to protect the environment. The dairy effluent generally has dilutions of milk products generated from washing of floor, storage means such as cans, tanks, milk spillage, liquid effluent of cheese, paneer and yoghurt production called whey. It has high Chemical Oxygen Demand (COD) due to presence of organic contents because of fats, proteins and carbohydrates. To reduce the effect of the dairy wastewater on the environment, it is necessary to adapt some advanced techniques. Generally, all the food industries including the dairy industry look upto the membrane processes to recycle and reuse the wastewater. Membrane filtration is not only used for reclamation and reuse but also for fractionation of whey, recovery from cleaning solutions and various other processes. Thus, this paper is a mini review which gives various details about the dairy industry wastewater.
\end{abstract}

Keywords - Dairy, milk, recovery, treatment, washing, wastewater

\section{INTRODUCTION}

The quality of the surface water has deteriorated drastically, states the CPCB report,2011 (Buabeng-Baidoo et al. 2017). The decrease in the availability of fresh water sources, increase in the cost of procurement of fresh water and generation of huge quantity of effluent has led us to think in the direction of industrial wastewater recycle and reuse (Vourch et al. 2008; Tompe and Wagh 2017). The dairy sector in India is the largest in the world. Milk demand increase with the increase in population (Mulla et.al, 2015). It generates about 6 to 10 litres of effluent per litre of processed milk depending upon the products made in the industry, quantity available and carefulness in usage of water(IS 8682:1977). According to the report published in 2014, dairy consumes about 62 billion $\mathrm{m}^{3}$ of fresh water annually and is expected to

\author{
Dr. D.D.Sarode \\ Department of General Engineering \\ Institute of Chemical Technology, Mumbai, \\ Maharashtra, India-400019
}

rise to 400 billion $\mathrm{m}^{3}$ by 2025(Buabeng-Baidoo et al. 2017). Among all the food industries, dairy industry is the most polluting industry in terms of water consumption and wastewater generation(Nagappan, Phinney, and Heldman 2018; Ghatawat et al. 2019). It consumes about $33.96 \%$ of water used in all food industries (Nagappan, Phinney, and Heldman 2018). The dairy industry consumes water in Cleaning In Place (CIP) process, in cooling tower operation, as boiler feed and as ingredient in various processes(Nagappan, Phinney, and Heldman 2018; Ezugbe and Rathilal 2020).

\section{STANDARD CODE FOR DAIRY WASTEWATER}

IS 8682:1977 is the Indian standard code for treatment and disposal of effluents from the dairy and allied industry. This code is a complete compilation of various sources of effluents along with their nature and volume of ill effects with the methods of their prevention, treatment and disposal. The dairies in India mostly make pasteurized and homogenised milk along with ghee from the sour milk(Tompe and Wagh 2017). Some dairies produce ice-cream, cheese, powdered milk, condensed food, baby food, cheese and channa with a few making casein(Shete and Shinkar 2016). India is also experiencing the increase in the production of skimmed milk and tonned milk and in the manufacturing of the cheese products in the recent years. (IS 8682:1977).

\section{DAIRY WASTEWATER EFFLUENT}

According to the wastewater generation standards, allowed wastewater generation in dairy is $3 \mathrm{~m}^{3} / \mathrm{KL}$ of milk processed(EPA rules 1986). Nearly $2 \%$ of the milk handled in the dairy goes as a waste (Mehrotra and Trivedi 2018). Wastewater effluent is simple diluted milk and highly biodegradable (Patil, Ahire, and Hussain 2014). The milk has fats, proteins, lactose, minerals and total solids which contributes to the organic content(Ghatawat et al. 2019). The dairy effluent generally has dilutions of milk products from washing of floor, milk spillage, liquid effluent of cheese, paneer, yoghurt production called whey(Vidal et al. 2000; Patil, Ahire, and Hussain 2014). This is always with salts, minerals, detergents, sanitizers, caustic soda, citric acid from 
the CIP process, washings from truck, cans, tankers, storage tanks etc (Mehrotra and Trivedi 2018; Mulla Sutar Ranveer 2015). CIP consumes the most water in dairy industry and also contributes maximum to the effluent generated with high $\mathrm{pH}$ and salt concentration(Nagappan, Phinney, and Heldman 2018). Table 1 indicates the sources of effluents in dairy industry and its general constituents.

Table-1 Sources and constituents of effluents from dairy industry (IS 8682:1977)

\begin{tabular}{|c|c|c|}
\hline Sr.No. & $\begin{array}{l}\text { Sources of effluents in } \\
\text { dairy industry }\end{array}$ & General constituents \\
\hline 1 & $\begin{array}{llr}\text { Effluents from } & \text { washing } \\
\text { cans of milk receiving } \\
\text { stations }\end{array}$ & $\begin{array}{l}\text { The wash water consists of } \\
\text { milk drippings, rinsing and } \\
\text { washing }\end{array}$ \\
\hline 2 & $\begin{array}{ll}\text { Effluents } & \text { from } \\
\text { pasteurization plant } & \end{array}$ & $\begin{array}{l}\text { It contains washing of } \\
\text { equipments which contain } \\
\text { acid, alkalies, detergents, } \\
\text { floor washing, spills and } \\
\text { leaks }\end{array}$ \\
\hline 3 & $\begin{array}{l}\text { Effluents from manufacture } \\
\text { of butter and ghee }\end{array}$ & $\begin{array}{l}\text { Buttermilk, washing of } \\
\text { churns and small quantity of } \\
\text { butter. Sometimes whole } \\
\text { milk, skim milk or cream } \\
\text { can also be present. }\end{array}$ \\
\hline 4 & $\begin{array}{l}\text { Effluents from manufacture } \\
\text { of cheese }\end{array}$ & $\begin{array}{l}\text { Main is discarded whey and } \\
\text { washings from vats with that } \\
\text { of drains, floor and presser }\end{array}$ \\
\hline 5 & Effluents from casein plant & $\begin{array}{l}\text { Whey of milk, mineral acids } \\
\text { used for precipitation and } \\
\text { washings }\end{array}$ \\
\hline 6 & $\begin{array}{l}\text { Effluent from bottle } \\
\text { washing plant (bottles and } \\
\text { crates) }\end{array}$ & $\begin{array}{l}\text { Alkaline effluent due to use } \\
\text { of detergents/ caustic soda }\end{array}$ \\
\hline 7 & $\begin{array}{l}\text { Effluent from water } \\
\text { softening plant and boiler } \\
\text { house }\end{array}$ & $\begin{array}{l}\text { Depending on the use of } \\
\text { resins, acidic or highly } \\
\text { acidic or saline effluents } \\
\text { along with suspended solids }\end{array}$ \\
\hline 8 & $\begin{array}{l}\text { Uncontaminated cooling } \\
\text { water }\end{array}$ & $\begin{array}{l}\text { Although cooling water can } \\
\text { be reused, some cooling } \\
\text { water is bled off to prevent } \\
\text { built off inorganics and } \\
\text { scaling effects }\end{array}$ \\
\hline 9 & $\begin{array}{l}\text { Human activities- Toilet, } \\
\text { Sanitation }\end{array}$ & Faecal coliforms, pathogens \\
\hline
\end{tabular}

\section{OPPORTUNITIES FOR WASTE REDUCTION AND BY-PRODUCT RECOVERY FROM DAIRY EFFLUENT}

To make dairy operations more efficient and economical, reduction of wastage and recovery of useful material from waste should be attempted. To achieve this, we need to understand basic operations and adopt some of the methods / procedures listed here:
1. Waste Reduction-This can be achieved by cleaning cans properly with the help of fine spray, preventing overflow, boil over, checking and maintenance of joints to prevent leaks and foaming in pipelines. The reduction in volume of waste by separating clean water from concentrated wastes (Mavrov, Chmiel, and Bélières 2001; IS code 8682:1977 2009).

2. Reclamation of waste products- In abroad, it is used for primary rinsing for feeding animals, for breeding, concentrated and evaporated whey effluent as well yeast on whey as feed for animals (IS code 8682:1977 2009; Azadi, Falahzadeh, and Sadeghi 2015).

3. By Product Recovery- (IS code 8682:1977 2009; Brião et al. 2019; Blandin et al. 2020)

- Butter milk- Recovery of total solids after roller drying and preliminary condensation. The dried powder can be a good source of protein.

- Whey-Pre-condensing in evaporators and spray drying can lead to recovery of whey and used as source of protein in animal feeds.

- Lactose- Whey and milk contains lactose in huge amount. Lactose from whey can be utilized in culturing of yeast which can be used as animal feed.

- Casein-Caseins can be recovered from sour milk by treating with acid and used in the manufacture of resins, plastics, paints and varnishes.

- Butter-Sour or rancid turned butter or cream can be used as raw material in vegetable oil factories.

Dairy wastewater is highly organic in nature. It has high Chemical Oxygen Demand (COD) due to presence of organic contents because of fats, proteins and carbohydrates (Nagappan, Phinney, and Heldman 2018; Wojciech, Beata, and Magdalena 2016). If untreated dairy wastewater is let out in the natural water bodies, it causes eutrophication due to high organic content and excessive nitrogen and phosphorus content(Nagappan, Phinney, and Heldman 2018).

\section{POLLUTION CAUSING EFFECTS OF DAIRY WASTEWATER WHEN DISCHARGED IN DIFFERENT SOURCES:}

1. Discharge in Inland surface water-

- Depletion of Dissolved Oxygen (DO)- This is the most important problem associated with the dairy industry effluent. When discharged into open nallah or ponds there may be putrefaction due to formation of lactic acid and butyric acid by rapid degradation of lactose, foul odours, breeding of fly, grease floating, growth of aquatic (IS code 8682:1977 2009; Velpula 2017)

- Effect on Fishes- A dilution of 1:15 dairy effluent, excluding whey, has distressing effect on fish. At dilution of $1: 35$, whey can prove toxic to fishes 
within few hours. Soap, lactic acid, butyric acid all are toxic to fishes (IS code 8682:1977 2009; Aydiner et al. 2013).

- Pathogens: Dairy effluent do not contain high number of pathogenic bacteria.

- Radioactivity: Milk as well its effluents can facilitate to concentrate strontium 90 especially on pastures contaminated with radioactive products or fallouts of fission products (IS code 8682:1977 2009; Niamsuwan, Kittisupakorn, and Mujtaba 2011)

2. Discharge on land-

Not all soils are suitable for this purpose. Heavy soils can cause anaerobic conditions to develop with foul odours and ponding, if irrigation system is not designed properly (IS code 8682:1977 2009; Slavov 2017).

3. Discharge into public sewers-

The possibility of sewer water becoming septic in sewer only and more pre-treatment can be required for aeration in sewage treatment plant due to presence of carbohydrates and high temperature of discharge (IS code 8682:1977 2009; Wang et al. 2017).

\section{DAIRY WASTEWATER TREATMENT PLANT}

The motive behind designing wastewater treatment systems is to reduce or eliminate contaminants to satisfy discharge regulations. If dairy does not have its own wastewater treatment plant, it sends the effluent to municipal wastewater treatment plant (MWWTP). The MWWTP has set limits for the influent COD, BOD, $\mathrm{pH}$, TDS and if dairy influent exceeds it, they have to pay the penalty. Thus, before discharging the water to waterbodies, treatment is necessary (Nagappan, Phinney, and Heldman 2018). Typical wastewater from all over the world has average COD of about $4000 \mathrm{mg} / \mathrm{l}$, whereas in India it is 500-800 mg/l (Mehrotra and Trivedi 2018). This difference is due to nature of products produced in India and abroad. The dairy industry effluent varies from hour to hour with maximum in afternoon, which is five times of average generally (IS 8682:1977). The $\mathrm{pH}$ value, alkalinity, total solids, suspended solids, BOD, COD, oil and grease characteristics of dairy influent and effluent are monitored(Brião et al. 2019). Protein, fat, lactose, total solids, organic solids and BOD of milk and by products are checked(Chandrasekhar 2017).

The five steps in principle for dairy wastewater treatment are 1)Screening, 2)Oil and grease traps, 3)Flow equalization, 4)Activated sludge process, 5)Tertiary treatment along with the reduction of pollution index and reduction in volume and strength of wastewater (Mulla et.al, 2015). According to the IS 8682:1977 of dairy treatment, the wastewater plant for dairy should have following units: Screening, Grease traps, Plain sedimentation, Coagulation and flocculation, Equalization and pre-aeration, Biological treatment which can be done by trickling filter, activated Sludge Process, oxidation ditch, aerobic ponds, anerobic ponds or stabilization ponds (IS 8682:1977). Focus should not only be on treatment but to reduce cost and efficiency of process and increase profit (Liberman 2018; Aydiner et al. 2014)

The treatment process recommended especially for India by IS 8682:1977 states that dairy treatment plant should have preliminary, primary (with dilution of wastewater) and secondary operations. Secondary operations can be done by oxidation ditch, aerobic lagoons, anaerobic lagoons followed by stabilization ponds. Anaerobic lagoon detention for 10 days would help to reduce BOD by $90 \%$ followed by anaerobic lagoon and oxidation pond or dilution to remove residual BOD(IS 8682:1977). Later on, the effluent can be disposed off on agricultural land in irrigation system, drip irrigation, spray irrigation, flood irrigation or furrow if BOD level of effluent is brought below $500 \mathrm{mg} / \mathrm{l}$. The Environment (Protection) Rules, 1986, Schedule VI gives the general standards for discharge of Environmental Pollutants as mentioned in Table 2.

\section{VARIOUS WAYS TO TREAT DAIRY WASTEWATER}

To reduce the effect of the dairy wastewater on the environment, it is necessary to adapt some advanced techniques(Mulla et.al, 2015). The available treatment methods for dairy wastewater are aerobic, anaerobic, dissolved air flotation (DAF), clarrifloculators, advanced oxidation process, activated sludge process, sand bio filters, electrocoagulation, moving bed biofilm reactors, etc.(Nagappan, Phinney, and Heldman 2018). Among the many methods, physio-chemical and biological methods are used mainly to treat the dairy wastewater (Danalewich et al. 1998; Vidal et al. 2000; Al-Shammari et al. 2015). However some studies report the inefficiency of physical process and high cost involved in COD removal through chemical processes(Al-Shammari et al. 2015). The biological process shows good organic removal and better quality effluent (AlShammari et al. 2015). The $\mathrm{pH}$ of the wastewater generated by some automated cleaning systems varies between 12 to 13 . To immobilize biomass for the reduction in $\mathrm{COD}, \mathrm{BOD}_{5}$ and suspended solids of dairy wastewater, biofilm supported media including bricks, foam, gravel was studied and results displayed that the nature and properties of support material. (Qazi et al. 2011).

Table-2 General standards for the discharge of pollutants (EPA rules 1986) 


\begin{tabular}{|l|l|l|l|l|l|}
\hline $\begin{array}{l}\text { Sr. } \\
\text { No. }\end{array}$ & Parameters & $\begin{array}{l}\text { Inland } \\
\text { surface } \\
\text { water }\end{array}$ & $\begin{array}{l}\text { Public } \\
\text { sewer }\end{array}$ & $\begin{array}{l}\text { Land for } \\
\text { irrigation }\end{array}$ & $\begin{array}{l}\text { Marine/coastal } \\
\text { areas }\end{array}$ \\
\hline 1. & pH value & $5.5-9.0$ & $5.5-9.0$ & $5.5-9.0$ & $5.5-9.0$ \\
\hline 2. & $\begin{array}{l}\text { BOD }(5 \\
\left.\text { days, 20 }{ }^{\circ} \mathrm{C}\right)\end{array}$ & 30 & 350 & 100 & 100 \\
\hline 3. & COD & 250 & - & - & 250 process \\
\hline 4. & $\begin{array}{l}\text { Suspended } \\
\text { solids } \\
(\mathrm{mg} / \mathrm{l}), \max \end{array}$ & 100 & 600 & 200 & $\begin{array}{l}\text { For coling } \\
\text { wastewater-1000 } \\
\text { For of } \\
\text { water effluent- } \\
10 \% \text { above total } \\
\text { suspended } \\
\text { matter } \\
\text { effluent cooling } \\
\text { water }\end{array}$ \\
\hline 5. & $\begin{array}{l}\text { Inorganic } \\
\text { Dissolved } \\
\text { solids (mg/l) }\end{array}$ & 2100 & 2100 & 2100 & \\
\hline
\end{tabular}

\section{MEMBRANE SYSTEM FOR TREATMENT OF DAIRY WASTEWATER}

In recent years, shift has been seen towards membrane technologies (Microfiltration, Ultrafiltration, Nanofiltration, Reverse Osmosis) rather than conventional technologies because of their more energy efficiency(Mavrov, Chmiel, and Bélières 2001; Demirel, Yenigun, and Onay 2005; AlShammari et al. 2015; Pramanik et al. 2019). Membrane technology works on the principle of selective permeability of components through membrane barrier(Jevons and Awe 2010; Al-Shammari et al. 2015). Generally, all the food industries including the dairy industry look at the membrane processes for water treatment for recycle and reuse(Ezugbe and Rathilal 2020). Microfiltration, nanofiltration, ultrafiltration, low pressure reverse osmosis, two stage nanofiltration, two stage reverse osmosis, integrated membrane process such as nanofiltration and reverse osmosis have been stated to be convenient by several works(Vourch et al. 2008; Kale et al. 2017). Forward osmosis for concentration of waste streams in food and dairy industry has attracted the research interests in recent years due to its low energy consumption and advancement in fabrication of membranes(Wang et al. 2017). Membrane filtration is not only used for reclamation and reuse but also for fractionation of whey, recovery from cleaning solutions and various other processes(Nagappan, Phinney, and Heldman 2018).

\section{CONCLUSION}

Dairy industry consumes and generates huge quantity of wastewater which tends to increase with the production of milk for the growing population. The highly organic wastewater needs to be reused and recycled to partly fulfill the huge demand by the dairy industry. The fresh water needs to be recovered in any form from the diluted waste concentrations to solve the growing water problems of the earth. As compared to many conventional technologies, membrane technologies provide economical and energy efficient solutions for the recovery and reuse of wastewater. Microfiltration, nanofiltration, ultrafiltration, low pressure reverse osmosis, two stage nanofiltration, two stage reverse osmosis, integrated membrane process such as nanofiltration and reverse osmosis have been stated to be convenient. Forward osmosis is the growing technology in the food sector, for the concentration and recovery from the wastewater. As dairy wastewater fluctuates too much in volume and quality, thus heterogenous wastewater treatment processes are the best options. Final selection of treatment process will depend on volume to be treated, water scarcity, interest of dairy authorities and availability of funds.

\section{REFERENCES:}

1. Al-Shammari, Bou-Hamad S, Al-Saffar A, Salman M, and Al-Sairafi A. 2015 "Treatment of Dairy Processing Wastewater Using Integrated Submerged Membrane Microfiltration System" 5 (4).

2. Aydiner, Coskun, Unal Sen, Semra Topcu, Duygu Sesli, Didem Ekinci, Aysegul Derya Altinay, Bahar Ozbey, Derya Yuksel Koseoglu-Imer, and Bulent Keskinler. 2014 "Techno-Economic Investigation of Water Recovery and Whey Powder Production from Whey Using UF/RO and FO/RO Integrated Membrane Systems." Desalination and Water Treatment 52 (1-3): 123-133.

3. Aydiner, Coskun, Semra Topcu, Caner Tortop, Ferihan Kuvvet, Didem Ekinci, Nadir Dizge, and Bulent Keskinler. 2013. "A Novel Implementation of Water Recovery from Whey: "Forward- Reverse Osmosis' Integrated Membrane System." Desalination and Water Treatment 51 (4-6): 786799.

4. Azadi, Nammam Ali, Reza Ali Falahzadeh, and Shahram Sadeghi. 2015. "Dairy Wastewater Treatment Plant in Removal of Organic Pollution : A Case Study in Sanandaj, Iran" 2 (2): 73-77.

5. Blandin, Gaetan, Federico Ferrari, Geoffroy Lesage, Pierre Le-Clech, Marc Héran, and Xavier MartinezLladó. 2020. "Forward Osmosis as Concentration Process: Review of Opportunities and Challenges." Membranes 10 (10): 1-40.

6. Brião, Vandré Barbosa, Ana Cláudia Vieira Salla, Taizi Miorando, Marcelo Hemkemeier, and Danúbia Paula Cadore Favaretto. 2019. "Water Recovery from Dairy Rinse Water by Reverse Osmosis: Giving Value to Water and Milk Solids." Resources, Conservation and Recycling 140 (January 2018): 313-23..

7. Buabeng-Baidoo, Esther, Nielsen Mafukidze, Jaideep Pal, Sarojini Tiwari, Babji Srinivasan, Thokozani 
Majozi, and Rajagopalan Srinivasan. 2017. "Study of Water Reuse Opportunities in a Large-Scale Milk Processing Plant through Process Integration." Chemical Engineering Research and Design 121: 126.

8. Chandrasekhar, S. S. 2017. "Treatment of Dairy Industry Effluent Using Membrane Bioreactor." International Journal of Pure \& Applied Bioscience 5 (6): 71-79.

9. Danalewich, J. R., T. G. Papagiannis, R. L. Belyea, M. E. Tumbleson, and L. Raskin. 1998. "Characterization of Dairy Waste Streams, Current Treatment Practices, and Potential for Biological Nutrient Removal." Water Research 32 (12): 355568.

10. Demirel, Burak, Orhan Yenigun, and Turgut T. Onay. 2005. "Anaerobic Treatment of Dairy Wastewaters: A Review." Process Biochemistry 40 (8): 2583-2595.

11. EPA rules, 1986. 1986 "General Standards for Discharge of Environmental Pollutants." The Environment (Protection) Rules 2 (174): 545-60.

12. Ezugbe, Elorm, and Sudesh Rathilal. 2020 "Membrane Technologies in Wastewater Treatment:"

13. Ghatawat, Pritesh, Vankar Yogesh, Supriya Dhume, and Chendake Yogesh. 2019 "Separation and Recovery of Milk Components from Dairy Effluent" 8 (06): 884-88.

14. IS code 8682:1977. 2009 "Guide for Treatment and Disposal of Effluents of Dairy Industry."

15. Jevons, Kamla, and Martin Awe. 2010 "Economic Benefits of Membrane Technology vs. Evaporator." Desalination 250 (3): 961-963.

16. Kale, Swapnil, Prof R S Sangitrao, Shubham Khedekar, Gajanan Inamdar, and Shubham Mohite. 2017 "Automated Cleaning in Dairy Industry Using CIP Method." International Journal of Innovative Science and Research Technology 2 (4): 274-277.

17. Liberman, Boris. 2018 "Three Methods of Forward Osmosis Cleaning for RO Membranes." Desalination 431: 22-26.

18. Mavrov, V., H. Chmiel, and E. Bélières. 2001 "Spent Process Water Desalination and Organic Removal by Membranes for Water Reuse in the Food Industry." Desalination 138 (1-3): 65-74.

19. Mehrotra, Rakesh, and A Trivedi. 2018. "Study on characterisation of Indian Dairy Wastewater" 1 (11): 77-88.

20. Mulla Sutar Ranveer, Riyaj Azim Anil. 2015. "Study of Various Technologies Available For Treatment of Dairy Wastewater- A Review,".

21. Nagappan, Subbiah, David M Phinney, and Dennis Heldman. 2018 "Management of Waste Streams from Dairy Manufacturing Operations Using Membrane
Filtration and Dissolved Air Flotation." Applied Sciences 8 (12).

22. Niamsuwan, Sathit, Paisan Kittisupakorn, and Iqbal M. Mujtaba. 2011 "Minimization of Water and Chemical Usage in the Cleaning in Place Process of a Milk Pasteurization Plant." Songklanakarin Journal of Science and Technology 33 (4): 431-440.

23. Patil, Swati A, Vaishali V Ahire, and M H Hussain. 2014. "Dairy Wastewater-a Case Study Dairy Wastewater-a Case Study." International Journal of Research in Engineering and Technology 3 (9): 3034.

24. Pramanik, Biplob Kumar, Faisal I. Hai, Ashley J. Ansari, and Felicity A. Roddick. 2019 "Mining Phosphorus from Anaerobically Treated Dairy Manure by Forward Osmosis Membrane." Journal of Industrial and Engineering Chemistry 78: 425-432.

25. Qazi, Javed Iqbal, Muhammad Nadeem, Shagufta S Baig, Shahjahan Baig, and Quratulain Syed. 2011 "Anaerobic Fixed Film Biotreatment of Dairy Wastewater." Middle-East Journal of Scientific Research 8 (3): 590-593.

26. Shete, Bharati S, and N P Shinkar. 2013 "Comparative Study of Various Treatments For Dairy Industry Wastewater Comparative Study of Various Treatments For Dairy Industry Wastewater", IOSR Journal of Engineering- 3(8): 42-47.

27. Slavov, Aleksandar Kolev. 2017 "General Characteristics and Treatment Possibilities of Dairy Wastewater -a Review." Food Technology and Biotechnology 55 (1): 14-28.

28. Tompe, A.S., and C.H. Wagh. 2017 "A Review on Different Methods of Dairy Wastewater Treatment", International Journal of Recent Research Aspects, 4 (4): 443-445.

29. Velpula, Suresh , 2017 "Dairy Wastewater Treatment by Membrane Systems - A Review." International Journal of Pure \& Applied Bioscience 5 (6): 389 395.

30. Vidal, G., A. Carvalho, R. Méndez, and J. M. Lema. 2000 "Influence of the Content in Fats and Proteins on the Anaerobic Biodegradability of Dairy Wastewaters." Bioresource Technology 74 (3): 231239.

31. Vourch, Mickael, Béatrice Balannec, Bernard Chaufer, and Gérard Dorange. 2008 "Treatment of Dairy Industry Wastewater by Reverse Osmosis for Water Reuse", Desalination (219), 190-202.

32. Wang, Yi Ning, Rong Wang, Weiyi Li, and Chuyang Y. Tang. 2017 "Whey Recovery Using Forward Osmosis - Evaluating the Factors Limiting the Flux Performance." Journal of Membrane Science 533.

33. Wojciech, Dąbrowski, Karolinczak Beata, and Gajewska Magdalena. 2016 "Application of Subsurface Vertical Flow Constructed Wetlands to 
International Journal of Engineering Applied Sciences and Technology, 2021

Vol. 6, Issue 1, ISSN No. 2455-2143, Pages 363-368

Published Online May 2021 in IJEAST (http://www.ijeast.com)

Reject Water Treatment in Dairy Wastewater

Treatment Plant”, Environmental Technology . 